\title{
Farming Muskoxen for Qiviut in Alaska: A Feasibility Study
}

\author{
Laura Starr, ${ }^{1,2}$ Joshua Greenberg$^{1}$ and Janice Rowell ${ }^{1}$
}

(Received 17 November 2015; accepted in revised form 28 July 2016)

\begin{abstract}
Muskoxen (Ovibos moschatus) have been farmed since the 1960s for their fiber, called qiviut, a luxurious and highly valued underwool that is their primary insulation during the Arctic winter. Muskoxen are uniquely adapted to the Arctic. They thrive on local forages, do not require protection from the cold, and adapt well to many traditional husbandry practices. While muskoxen can be farmed for qiviut, the question remains whether it is an economically feasible and potentially sustainable enterprise in subarctic Alaska. This feasibility study was conducted using an enterprise budget for two herd sizes, 36 and 72 muskoxen, to estimate the principal costs and model different sales combinations. Under several revenue-generating scenarios, the feasibility study indicated a potential for economic viability of an established enterprise. The most profitable scenario for either herd size was selling all the qiviut as value-added yarn, coupled with livestock sales. In the absence of selling livestock, the enterprise was profitable at either scale assuming all the qiviut was sold as yarn. Selling qiviut solely as raw fiber was not projected to break even under the model parameters. The modeled enterprise emphasized the importance of value-added goods, economies of scale, low or zero opportunity costs, and the potential of a more active livestock market.
\end{abstract}

Key words: economic feasibility; qiviut; muskox; sustainability; enterprise budget; indigenous livestock; place-based agriculture

RÉSUMÉ. Le bœuf musqué (Ovibos moschatus) est élevé depuis les années 1960 pour sa fibre, appelée qiviut, ce duvet somptueux et fort prisé qui sert d'isolant principal à cet animal pendant les hivers de l'Arctique. Le bœuf musqué est remarquablement bien adapté à l'Arctique. Il se nourrit d'aliments qui se trouvent dans la région, n'a pas besoin d'être protégé du froid et se prête bien à de nombreuses pratiques traditionnelles d'élevage. Bien qu'il soit possible d'élever le bœuf musqué pour son qiviut, il n'en reste pas moins qu'il faut se demander s'il s'agit là d'une entreprise rentable et durable dans le subarctique de l'Alaska. Cette étude de faisabilité a été réalisée à l'aide d'un budget d'entreprise pour des troupeaux de deux tailles, soit un troupeau de 36 bœufs musqués et un troupeau de 72 bœufs musqués, afin d'évaluer les principaux coûts et de modéliser diverses combinaisons de ventes. À l'aide de plusieurs scénarios de génération de revenus, l'étude de faisabilité a indiqué des possibilités de rentabilité économique pour une entreprise établie. Le scénario le plus rentable pour l'une ou l'autre taille de troupeau consistait à vendre tout le qiviut en tant que laine à valeur ajoutée, alliée à la vente du bétail. En l'absence de la vente de bétail, l'entreprise était rentable à l'une ou l'autre des échelles, en présumant que tout le qiviut était vendu en tant que laine. La vente du qiviut en tant que fibre brute seulement ne donnait pas lieu à la projection d'un seuil de rentabilité d'après les paramètres du modèle. L'entreprise ayant fait l'objet du modèle mettait l'accent sur l'importance des biens à valeur ajoutée, des économies d'échelle, de coûts faibles ou nuls et de la possibilité d'un marché plus actif pour le bétail.

Mots clés : rentabilité économique; qiviut; bœuf musqué; durabilité; budget d'entreprise; bétail indigène; agriculture adaptée au milieu

Traduit pour la revue Arctic par Nicole Giguère.

\section{INTRODUCTION}

The term "sustainable agriculture" denotes sitespecific farming systems that provide for human food and fiber in perpetuity by enhancing the environment, conserving scarce resources, enriching personal lives and communities, and ensuring economic viability for the long term (Kornegay et al., 2010). In addition to being limited by the obvious climatic and geographical constraints, sustainable agriculture in Alaska must also compete with the high yields and low prices of agricultural products from the lower 48 states. The ecological and economic challenges of sustainable agriculture in Alaska are most evident when farming methods and species developed for temperate climates are imposed on a northern landscape. In order to shift this paradigm, we need to embrace a broader vision of agriculture that includes indigenous, non-traditional species and farming practices, while exploring niche markets.

The muskox (Ovibos moschatus), a native Arctic ruminant, fits these primary criteria (Rowell et al., 2007). Muskoxen are indigenous to the Arctic and well adapted to the extreme climate and landscapes of the circumpolar

\footnotetext{
${ }^{1}$ School of Natural Resources and Extension, University of Alaska Fairbanks, PO Box 757140, Fairbanks, Alaska 99775-7140, USA

${ }^{2}$ Corresponding author: 1mstarr@alaska.edu

(C) The Arctic Institute of North America
} 
North. They produce a luxury fiber, qiviut, for which niche markets currently exist. We know that muskox farming supports two of the three components of the sustainability triad: ecological compatibility and social and cultural acceptance in Alaska. This paper discusses the third critical criterion for sustainable agricultural practices: the economic viability of muskox farming.

Muskoxen were reintroduced to Alaska in the 1930s, and today wild populations can be found north of the Brooks Range, on the Seward Peninsula, and on Nunivak Island (Jones and Perry, 2013). A muskox herd was established in Fairbanks in 1964 with the intent of domesticating muskoxen for commercial fiber production (Watson and Groves, 1989). The Alaska State Legislature (2014) has declared muskoxen an agricultural species that can be legally farmed in the state. The emerging consensus from 50 years of muskox farming is that husbandry is not inherently different from that of more traditional livestock raised in northern climates (J. Blake, pers. comm. 2014).

Muskoxen generally share the temperament and nutritional requirements of goats and require the fencing and handling infrastructure used for bison and other nontraditional livestock (J. Blake, pers. comm. 2014). Because they are adapted to circumpolar habitats, muskoxen require no shelter from subzero temperatures or fresh water once there is sufficient snow, which reduces dependence on heat and water utilities and infrastructure. This advantage is coupled with their ability to maintain adequate body mass on low-protein forages through a combination of low metabolic requirements and efficient digestion; in contrast, cattle require more than twice the daily dry matter intake of muskoxen for the same body mass (Adamczewski et al., 1994). The ability of the muskox to graze successfully on marginal lands and use low-protein forage enables producers to exploit previously unproductive land holdings. This ability is an important consideration in Alaska, where land is often unimproved, difficult to access, and costly (or impractical) to convert to traditional agricultural or commercial uses.

Adult muskoxen weigh an average of $300 \mathrm{~kg}$ (males) and $200 \mathrm{~kg}$ (females), and the life expectancy for females and castrates can exceed 20 years (White et al., 1997). Females breed once they reach $180-227 \mathrm{~kg}$ (at 2-3 years old) and are capable of producing one calf per year (White et al., 1997). In the Fairbanks herd, rut typically begins in August, and breeding is usually complete by September. Calves can be left with a tame mother or weaned between 2.5 and 4 months and then offered food treats (or a dilute milk substitute) to facilitate handling (Rowell, 1990).

The muskox's primary adaptation to cold is its pelage: long primary guard hairs cover a $4-8 \mathrm{~cm}$ thick layer of secondary fibers or underwool, named qiviut by the indigenous people (Robertson, 2000). Every spring, muskoxen shed qiviut in a highly synchronous manner, which enables it to be combed in luxuriant sheets from farmed animals (Fig. 1) (Rowell et al., 2001). Individuals shed $1.3-2.8 \mathrm{~kg}$ of qiviut, or approximately $1 \%$ of their

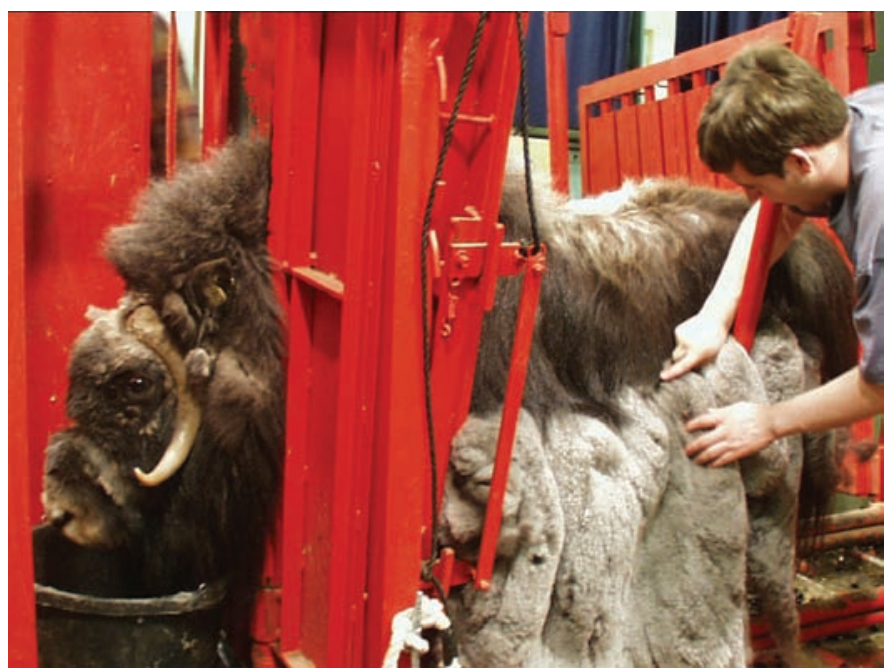

FIG. 1. A tame adult muskox being combed in the animal-handling squeeze at the Robert G. White Large Animal Research Station, University of Alaska Fairbanks. (Photo credit: Janice Rowell)

body weight, each year. Qiviut is considered a rare, luxury fiber, comparable to fine cashmere, vicuña, or guanaco (McGregor, 2012), and provides the economic potential for muskox farmers (Rowell et al., 2001). Qiviut's luxury characteristics, scarcity, and unique origin translate into high prices on fiber markets.

There are three ways of obtaining qiviut: it can be naturally shed by wild muskoxen and collected from the tundra, shaved or plucked from the hides of harvested wild animals, or combed from farmed muskoxen. Wild muskox populations provide the bulk of the fiber for today's qiviut industry. Qiviut products are popular with tourists who visit Alaska, and qiviut yarn, garments, and accessories from both wild and farmed muskoxen are successfully being marketed to established niche markets through the Internet and specialty boutiques (Cortright, 2006; Kissel, 2009). Luxury garments made of qiviut have achieved a celebrity following, and suits have been sold for as much as $\$ 25000$ (Kissel, 2009).

The economic potential of muskox farming has been recognized in North America for more than 60 years (Wilkinson and Teal, 1984), yet early muskox farm enterprises struggled to have their relatively small amounts of qiviut processed into value-added goods, gain access to developing niche markets, and find support for herd health and veterinary care. Many of these challenges have been diminished by advances in small custom mill processing, Internet sales, and research on muskox health and husbandry.

To date, the substantial startup costs, the risk associated with farming non-traditional species, and the lack of an active market for muskox livestock remain the greatest barriers to establishing new farms in Alaska. In light of the progress and potential, as well as the barriers and risk that influence muskox farming, an assessment of economic viability is a critical first step in establishing sustainable development. In this paper we model the principal 
FARMING MUSKOXEN FOR QIVIUT • 79

economic variables of a hypothetical, established farm in order to provide a basis for evaluating the sustainable economic potential of such an enterprise.

\section{METHODS}

The feasibility study was conducted using an enterprise budget to estimate the principal fixed and variable costs and model different revenue scenarios. The economic data for this enterprise budget have been extrapolated from two non-profit muskox facilities in Alaska, the only farms currently selling commercial quantities of qiviut. Cost and revenue information was based on 2012-14 data for the Robert G. White Large Animal Research Station (LARS) and 2013 data from the Musk Ox Development Corporation (MODC). The estimates used represent available data from both data sets. Interviews with experts and stakeholders in the field of muskox husbandry and cost quotes from suppliers in Fairbanks, Alaska, were used to project production costs that are not well represented by the nonprofit facilities. The enterprise budget constructed from these estimates was modeled on enterprise budgets from the bison and alpaca industries (Foulke et al., 2001; Bond, 2011). The resulting enterprise budget does not represent any particular facility or farm but rather a hypothetical farm whose operation we describe by amalgamating data from the sources listed above. The budget is intended to provide a general understanding of the commercial viability of farmed qiviut production in the North and the approximate costs and revenues associated with this endeavor.

\section{Enterprise Budget}

The enterprise budget was built upon a number of assumptions detailed below. The budget was constructed at two scales, 36 and 72 muskoxen on 16.19 ha and 32.38 ha, respectively, to accommodate a range of operation sizes. At the time of data collection, LARS had 25 muskoxen and MODC had 72. The MODC facility, with 72 muskoxen, represents an upper limit to potential economies of scale as the number of muskoxen was approaching the infrastructure and land area limitations of that facility (J. Curtis, pers. comm. 2014). The smaller scale of 36 muskoxen was chosen as a $50 \%$ reduction of the larger operation. The land requirements were based on the ability to feed a herd of each size the required $1320 \mathrm{~kg}$ (dry weight) forage during the summer season (120 d) without supplemental hay and a pasture productivity of $3000 \mathrm{~kg} / \mathrm{ha}$. All variable costs were assumed to be linear. All costs and revenues are reported in U.S. dollars. Tables 1 and 2 detail operating and depreciable costs, respectively, while Tables 3 and 4 present the value per $\mathrm{kg}$ of the qiviut harvest and potential revenues from its sale.

\section{Projected Costs}

Muskoxen consume approximately $4 \%-5 \%$ of their body weight per day in dry weight forage during summer (June-Sept) and 2\%-3\% during winter (Oct-May). This budget assumes sufficient pasture for each animal to graze $11 \mathrm{~kg}$ dry weight forage per day over 120 days of summer and $3.5 \mathrm{~kg}$ of hay per day from October to May. These figures are based on LARS mean herd body weight of $176 \mathrm{~kg}$ (used to calculate qiviut yield/kg body weight). The cost estimate for hay, also based on LARS costs, was $\$ 190$ per $363 \mathrm{~kg}$ bale. Pellet supplementation is essential all year long to compensate for pasture and hay deficiencies. A specially designed muskox ration is fed at a rate of $0.75 \mathrm{~kg}$ per animal per day, for a total annual ration of $272 \mathrm{~kg}$. Pelleted feed costs $\$ 20.50$ per $22.7 \mathrm{~kg}$ bag (Table 1).

It is assumed in the budget that the herd of muskoxen is consistently handled and that calves are not weaned early. Labor estimates were based on MODC and LARS practices and are similar to those for the sheep industry, which requires additional inputs for seasonal lambing and shearing (Kumm, 2009). In this analysis, the labor requirement is assumed to increase by approximately $50 \%$ as the herd increases by $100 \%$ (Kumm, 2009). The model assumes a herd of 36 muskoxen with a full-time owner present and a year-round, part-time employee to assist with handling, combing, calving, and taming animals. At the scale of 72 muskoxen, the permanent part-time position transitions to a full-time position during the summer season (mid May-August), and an additional part-time summer employee is required to meet the increased labor demands. The full-time owner was not included in the labor costs because he or she is the recipient of the stream of revenues from the enterprise. The year-round, skilled farm employee was budgeted at $\$ 15$ per hour and the seasonal, unskilled employee was budgeted at $\$ 10$ per hour. On the basis of Alaska requirements, payroll taxes were estimated to be $26 \%$. Consistent labor inputs are necessary for taming new calves and for the labor-intensive spring qiviut harvest and calving season to maintain a high level of productivity.

A comprehensive herd health program, developed in conjunction with a local veterinarian, establishes nutritional regimens and husbandry practices and sets and monitors goals for weight gain, reproductive performance, and production parameters. The program is designed to meet production goals and mitigate risk. The management assumptions in this modeled enterprise are based on the herd health program established at LARS through the UAF Animal Resources Center and incorporate associated veterinary fees. The herd health costs contain both fixed and variable cost components.

An annual fixed cost of $\$ 800$ for two veterinary consultation visits (two hours each at $\$ 200$ per hour) covers planning, analysis of records, review of vaccination and parasite control schedules, breeding and reproductive health, nutritional assessment and monitoring, and routine health maintenance. In conjunction with weight and 
TABLE 1. Estimated operating costs for a hypothetical muskox farm in Alaska at two herd sizes, 36 and 72 head. Assumptions are detailed in Methods under Enterprise Budget.

\begin{tabular}{|c|c|c|c|}
\hline \multirow[b]{2}{*}{ Operating expenses ${ }^{1}$} & \multirow[b]{2}{*}{ Price per unit } & \multicolumn{2}{|c|}{ Operating cost on a herd basis $(\$)$} \\
\hline & & Herd size 36 & Herd size 72 \\
\hline \multicolumn{4}{|l|}{ Feed } \\
\hline Hay $-363 \mathrm{~kg}$ bales & $\$ 190$ & 15960.00 & 31730.00 \\
\hline Grain ration $-22.68 \mathrm{~kg}$ bag & $\$ 20.50$ & 9000.00 & 18000.00 \\
\hline \multicolumn{4}{|l|}{ Hired labor } \\
\hline 1040 hours & $\$ 15 / \mathrm{hr}$ & 15600.00 & - \\
\hline 1240 hours & $\$ 15 / \mathrm{hr}$ & - & 18600.00 \\
\hline Summer -320 hours & $\$ 10 / \mathrm{hr}$ & - & 3200.00 \\
\hline Payroll tax (\% of labor costs) & $26 \%$ & 4056.00 & 5668.00 \\
\hline \multicolumn{4}{|l|}{ Veterinary care } \\
\hline Herd health consultation & $\$ 200 / \mathrm{hr}$ & 800.00 & 800.00 \\
\hline Emergency care & $\$ 200 / \mathrm{hr}$ & 540.00 & 1080.00 \\
\hline Vaccinations & $\$ 1.30 /$ dose & 118.80 & 237.60 \\
\hline Qiviut profile test & $\$ 9.50 /$ sample & 342.00 & 684.00 \\
\hline Misc. supplies & estimate & 1000.00 & 1500.00 \\
\hline Property taxes $(\$ 617.50 / \mathrm{ha})$ & $1.58 \%$ mill rate & 158.00 & 316.00 \\
\hline Insurance & insurance quote & 3500.00 & 4500.00 \\
\hline Interest on capital ${ }^{2}$ & $7 \%$ & 5062.55 & 7649.81 \\
\hline Internet/phone (per month) & $\$ 100$ & 1200.00 & 1200.00 \\
\hline Electricity/water/heat (per month) & $\$ 250$ & 3000.00 & 3000.00 \\
\hline Fence (repairs per $30.5 \mathrm{~m}$ ) & $\$ 270$ & 270.00 & 540.00 \\
\hline Vehicle and equipment (fuel/repair) & estimate & 3500.00 & 3500.00 \\
\hline Total operating costs & & $\$ 64107.35$ & $\$ 102205.41$ \\
\hline
\end{tabular}

${ }^{1}$ Assumed that the land is $100 \%$ operator-owned and therefore operating expenses do not include a cost for a land-purchase loan.

${ }^{2}$ Percentage of total costs (operating + depreciated).

reproduction records, qiviut yield and qiviut characteristics provide an indirect measure of herd health. The cost of measuring fiber quality (staple length and fiber diameter) to monitor qiviut characteristics was $\$ 9.50$ per sample (Yocom-McColl Testing Laboratories, Denver, Colorado). A separate, variable cost of $\$ 15$ per animal was assessed for emergency veterinary calls related to unforeseen illness, injury, and calving complications. Annual costs of $\$ 3.30$ per animal were included for vaccinations, which were assumed to be administered by farm employees along with routine care.

The opportunity cost of land in the enterprise budget is based on the potential cash rent landowners could receive if they chose not to farm the land themselves. This is a representation of the income available to the owner from the land in its next most highly valued use (Hofstrand, 2008). Since muskoxen are able to graze land that is not well suited to other agricultural or commercial uses, the cash rent and hence opportunity cost to the landowner to farm muskoxen is assumed to be zero. The land is considered an appreciating asset and is not included in the costs. Property taxes represent the cost of holding the land. Since land being used for agriculture is taxed at a reduced rate under the Fairbanks North Star Borough Farm Use Exemption Program, owners could reduce the cost of holding land by starting agricultural production on land not previously used for that purpose.

The enterprise budget assumes that all capital is borrowed at a commercial loan interest rate of $7 \%$ (Table 1). All costs were totaled, and a simple interest rate of $7 \%$ was applied to determine the capital cost of the enterprise.
The 7\% interest rate was applied to the depreciable costs in order to account for borrowing costs associated with the upfront purchase of depreciable items. (Individuals interested in constructing a startup muskox operation will need to adjust this assumption on the basis of available loan rates for operating and fixed capital and loan cost estimates based on separate loan schedules for assets.)

Depreciation costs are outlined in Table 2. The straight line method was used to calculate the annual depreciation (Boehlje and Eidman, 1984). Infrastructure for handling animals is not strictly necessary to farm muskoxen. MODC combs many animals in milking stalls, while another venture collected qiviut shed by muskoxen directly from the pasture. However, the largest yield comes from combing calm animals, so costs for a minimal handling facility were included in infrastructure estimates. (A video of a tame muskox being combed for qiviut can be found on YouTube [https://www.youtube.com/watch? $\mathrm{v}=\mathrm{uSFeO} 4 \mathrm{aN} \_0 \mathrm{~g}$ ].) The budget included a $6.10 \times 4.88 \mathrm{~m}$ pole barn at a cost of $\$ 12000$ depreciated for an expected lifespan of 20 years. Costs for other handling infrastructure (a chute and a squeeze) range from $\$ 8000$ to $\$ 24000$, depending on materials and configuration. This budget used an estimate of $\$ 14000$ depreciated over seven years. A truck and trailer, ATV, pull behind mowers, feed bunks, and water troughs were depreciated over a span of five years.

A variety of fence materials have been successfully used to contain muskoxen, including $2 \times 8$ inch wooden rails, wire game fencing, and both solid and open panel fencing. Bull pens are usually reinforced. LARS uses discarded highway guards or abandoned railway ties and cable. This 
TABLE 2. Estimated depreciated costs for a hypothetical muskox farm in Alaska at two herd sizes, 36 and 72 head. Assumptions are detailed in Methods under Enterprise Budget.

\begin{tabular}{|c|c|c|c|c|c|c|}
\hline \multirow[b]{2}{*}{ Depreciation costs ${ }^{1}$} & \multirow[b]{2}{*}{ Lifespan (yr) } & \multicolumn{2}{|c|}{ Value per unit (\$) } & \multirow[b]{2}{*}{ Total (\$) depreciated value } & \multicolumn{2}{|c|}{$\begin{array}{l}\text { Annual cost per } \\
\text { muskox herd (\$) }\end{array}$} \\
\hline & & New market value per unit & Residual value $^{2}$ & & Herd size 36 & Herd size 72 \\
\hline Pole barn & 25 & 12000.00 & 0.00 & 12000.00 & 480.00 & 480.00 \\
\hline Squeeze/chute & 10 & 14000.00 & 1000.00 & 13000.00 & 1300.00 & 1300.00 \\
\hline Mower & 10 & 1000.00 & 100.00 & 900.00 & 90.00 & 90.00 \\
\hline Truck and trailer & 6 & 50000.00 & 3000.00 & 47000.00 & 7833.33 & 7833.33 \\
\hline ATV & 10 & 7500.00 & 500.00 & 7000.00 & 700.00 & 700.00 \\
\hline Slanted feed bunks $-3.7 \mathrm{~m}$ & 10 & 800.00 & 0.00 & $4800.00(9600.00)^{3}$ & 480.00 & 960.00 \\
\hline Poly water tank - 435.31 & 10 & 80.00 & 0.00 & $480.00(960.00)^{3}$ & 48.00 & 96.00 \\
\hline Fence $-1.8 \mathrm{~m}$ on $3 \mathrm{~m}$ spans & 10 & 250 per $30.5 \mathrm{~m}$ & 0.00 & $23460.00(32680.00)^{3}$ & 2346.00 & 3268.00 \\
\hline Total & & & & & $\$ 13277.33$ & $\$ 14727.33$ \\
\hline
\end{tabular}

\footnotetext{
${ }^{1}$ Straight line depreciation $=($ new market value - residual value $) /$ lifespan.

${ }^{2}$ Residual value (or salvage value) is the value remaining after the asset has been fully depreciated over its expected lifespan.

${ }^{3}$ Depreciated cost that changes with herd size: herd of 36 (herd of 72).
}

budget assumed $183 \mathrm{~cm} \mathrm{14-gauge} \mathrm{welded} \mathrm{wire} \mathrm{fencing} \mathrm{for}$ the perimeter fence and $152.4 \mathrm{~cm} \mathrm{14-gauge} \mathrm{welded} \mathrm{wire}$ fencing for the interior fence. Fencing is stretched on $4 \times 4$ inch wooden posts at $3.05 \mathrm{~m}$ intervals. We calculated initial fencing costs (materials + construction) by estimating the perimeter of land area required (16.19 ha for a herd of 36 muskoxen; 32.38 ha for a herd of 72) and dividing the area into three paddocks. Initial fence construction costs have been depreciated over 15 years (Table 2). Separate costs for annual fencing repairs are estimated in general infrastructure upkeep (Table 1).

\section{Projected Revenue}

Qiviut can be sold as unprocessed raw fiber or processed at a custom mill and sold as finished yarn, or a combination of both. For a qiviut harvest sold as a combination of raw fiber and yarn, we assumed a sales breakdown of $60 \%$ raw fiber and $40 \%$ yarn. Six different scenarios were used to estimate revenue at both herd sizes. These were factor combinations with and without livestock sales, and $100 \%$ of qiviut sold as yarn, $100 \%$ of qiviut sold as raw fiber, or $40 \%$ yarn $/ 60 \%$ raw fiber sales (Table 3 ).

Table 4 details the expected costs, losses, and net value per $\mathrm{kg}$ of qiviut in raw and yarn form. Processing into yarn by custom mills results in fiber loss and incurs additional expense. In the specification of the modeled farms, an overall fiber loss of $45 \%$ is assumed for finished yarn (2013 LARS data), and the cost of custom processing is based on current rates posted by Still River Fiber Mill (www.stillriverfibermill.com). Retail price for the yarn, $\$ 85$ per 28.35 g skein (a hank or ball of yarn) or $\$ 2998$ per $\mathrm{kg}$ (gross value), is based on the average price from a 2015 Google Internet search. The value of yarn after accounting for processing costs, shipping, fiber losses, and transaction costs is $\$ 1335$ per harvested $\mathrm{kg}$ of qiviut. The selling price for raw qiviut (based on LARS sales in 2015) was $\$ 495$ per $\mathrm{kg}$ or $\$ 480$ after transaction costs. The processed yarn is assumed to be sold at craft fairs, farmer's markets, online, or on the farm; therefore, transaction costs are estimated using 2015 Etsy online venue fees of 3.5\% and point-of-sale Square $^{\circledR}$ reader for smart phone fees of $2.75 \%$. Raw sales to commercial merchants are assumed to have transaction costs of point-of-sale Square ${ }^{\circledR}$ reader. Selling products on Etsy includes a virtual "market stall" web page that accounted for the marketing activity. Shipping and handling were charged to the buyer.

In addition to qiviut, the sale of live muskoxen could be a substantial source of revenue. MODC and LARS receive many inquiries regarding potential livestock sales. In this model, it is assumed that the herd is established; $50 \%$ of the herd are females; and $50 \%$ of those females are producing calves. Half of the calves are kept for replacement and the other half (rounding up) are sold for $\$ 8000$ per head after transaction costs. The value of $\$ 8000$ was projected after interviewing industry experts and evaluating sporadic sales prices over the past 30 years (J. Blake, pers. comm. 2014). We assumed that five calves were sold from a herd of 36 muskoxen and 10 calves from the herd of 72. In terms of price per head and the number of livestock that could be sold at the expected reproductive parameters, this estimate is considered conservative (J. Blake, pers. comm. 2014).

\section{RESULTS}

The potential profitability and the break-even points of the different revenue scenarios and two herd sizes are presented in Figure 2. The projected costs and revenues indicate that the most profitable scenario for either herd size was selling all the qiviut as yarn coupled with livestock sales. This scenario was two to four times as profitable as the next best option, depending on the herd size. Selling a combination of yarn and raw qiviut along with livestock offered the second-best potential for profitability. In the absence of livestock sales, the enterprise was profitable at either scale assuming that all yarn sold at full retail price. Using a combination of $40 \%$ yarn sales and $60 \%$ raw qiviut 
TABLE 3. Income potential from the modeled revenue streams.

\begin{tabular}{|c|c|c|c|c|c|}
\hline & \multirow[b]{2}{*}{$\begin{array}{l}\text { Qiviut produced } \\
(\mathrm{kg} / \mathrm{yr})\end{array}$} & \multirow[b]{2}{*}{$\begin{array}{l}\text { Livestock available } \\
\text { (for sale/yr) }\end{array}$} & \multicolumn{3}{|c|}{ Qiviut and livestock revenue } \\
\hline & & & $\begin{array}{l}\text { Livestock } \\
\text { @ } 8000 / \text { head }\end{array}$ & $\begin{array}{l}\text { All qiviut sold raw } \\
\text { @ \$481/kg }\end{array}$ & $\begin{array}{l}\text { All qiviut sold as yarn } \\
\text { @ } \$ 1335 / \mathrm{kg}\end{array}$ \\
\hline Herd size 36 & 63.31 & 5 & 40000.00 & 30452.11 & 84518.85 \\
\hline Herd size 72 & 126.61 & 10 & 80000.00 & 60899.41 & 169024.35 \\
\hline
\end{tabular}

TABLE 4. Processing and transaction costs, percentage of fiber loss in processing, and expected revenue from $1 \mathrm{~kg}$ of combed qiviut sold as raw fiber or yarn.

\begin{tabular}{|c|c|c|c|c|}
\hline Qiviut & Processing loss (\%) & Processing cost $(\$)$ & Transaction cost ( $\%$ of sale value) & $\begin{array}{l}\text { Revenue (\$ per kg of combed qiviut) } \\
\text { after deducting losses and costs }\end{array}$ \\
\hline Raw & 0 & 0.00 & 2.75 & 481.00 \\
\hline Yarn & 45 & 372.30 & 6.25 & 1335.00 \\
\hline
\end{tabular}

only (no livestock sales), the enterprise broke even at a herd size of 84 muskoxen. A raw sales based operation was not projected to break even until the herd size far exceeded our theoretical maximum (126 muskoxen). Without livestock sales, variable costs were met when all of the qiviut was sold as yarn at both herd sizes and with a yarn/raw split at a herd size of 72 muskoxen. The results of a sensitivity analysis, in which labor and feed costs were projected to increase by $10 \%$, indicated that an increase in these key costs would not change the profitability status of the modeled outcomes.

The modeled results showed significant economies of scale not only for depreciated costs and utilities, but also for labor and herd health and veterinary expenses. As the herd doubled in size from 36 to 72 muskoxen, costs decreased by approximately $26 \%$ overall, $30 \%$ in labor, and $22 \%$ for herd health. The feasibility analysis also demonstrated that economic viability may be contingent on zero or low opportunity costs and favorable market conditions allowing yarn to be sold at full retail price.

\section{DISCUSSION}

This feasibility study models the profitability of an established farm to determine the potential economic sustainability of farming muskoxen in Fairbanks, Alaska. Using several revenue-generating scenarios, the analysis indicates the possibility for economic viability, the first step in a sustainable enterprise. The modeled enterprise emphasizes the importance of value-added goods such as yarn, economies of scale, and the potential for a more active livestock market. The lack of data from private enterprises limited this analysis to a broad accounting of cost variables, and results should be viewed in the context of the data sources.

Not addressed in this budget are startup costs, which are beyond the scope of the present study. Startup costs will vary widely depending on the assets an individual has already accrued. It should be noted that most enquiries LARS receives come from farmers interested in diversifying their current enterprise, not individuals

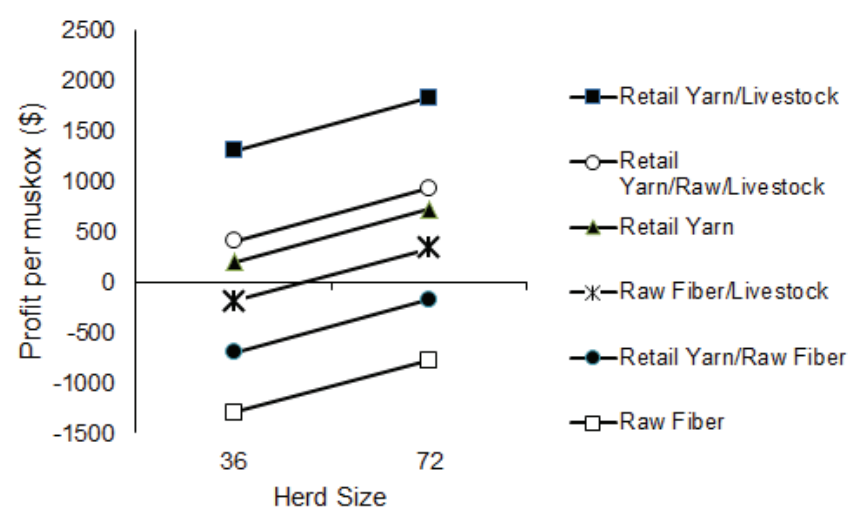

FIG. 2. Potential profit (total revenue - total cost) per head from six different revenue stream combinations of qiviut yarn, raw qiviut, and livestock (or no livestock) sales at two farm scales, 36 and 72 muskoxen. The break-even herd size for each modeled scenario is represented by the point at which the profit curve crosses the horizontal axis at zero profit.

starting with zero assets. In conjunction with startup costs, it is also important to consider the time it will take to establish a profitable herd, return on investment, and the associated risk of raising non-traditional livestock. All these considerations need to be factored into an individual's economic equation.

Sources for obtaining muskoxen are currently the greatest bottleneck to a beginning enterprise. In the past, muskoxen were purchased from zoos or private game farms, sources that are more restricted today. Although livestock sales could become a large source of revenue, producers need to exercise caution in an undeveloped market with few buyers and sellers. Other non-traditional livestock markets (emus, Shetland ponies, ostriches, and alpacas) have created speculative bubbles, where the sale of breeding stock becomes the main source of income, greatly elevating prices prior to their collapse (Gillespie and Schupp, 2002; Saitone and Sexton, 2007). The modeled muskox enterprise deliberately represented a scenario without livestock sales and demonstrated profitability selling yarn alone. In addition, we have intentionally avoided incorporating increasing livestock value or numbers of livestock sold into the model. 
While the enterprise budget broadly followed similar structures developed for bison and alpaca farming (Foulke et al., 2001; Bond, 2011), it also incorporates assumptions specific to farming muskoxen. The inclusion of fixed veterinary costs for the implementation of a proactive herd health plan is critical to mitigate health and management risks associated with raising a non-traditional species. This program is a mechanism to help the producer gain the information necessary to develop realistic production goals along with tools for monitoring the health and productivity of the animals. The consultations do not involve handling individual animals and are therefore a fixed cost relatively independent of herd size. Herd health further reduces labor costs by minimizing unplanned or emergency occurrences that require high labor inputs such as infirm animals, disease outbreaks, or unplanned reproductive events, while maximizing harvest yields, optimal breeding selections, and standardizing of husbandry techniques. If herd health is not made a priority, there is significant risk to the investment.

Consistent labor inputs beyond those associated with traditional livestock are required to accustom calves to people and handling procedures. Animals must be amenable to being handled in order to maximize comb qiviut yield every spring and accrue possible labor economies of scale (Robertson, 2000). While handling must be consistent, no special handling is necessary beyond familiarizing calves to farm routines such as coming through the squeeze chute, weighing, and moving between different pens. A previous research farm managed 120 head of muskoxen with two full-time employees (P. Groves, pers. comm. 2014).

Efforts to refine the combing process are underway. Research on qiviut and other fine fibers suggests that increases in raw yield are possible with nutritional advances, improved combing techniques, and coordinated timing for combing (Boyd et al., 1996; Robertson, 2000; Ansari-Renani et al., 2013). This enterprise model assumes that processing into yarn is done through small custom mills in the United States. Large commercial mills generally require hundreds of kilograms of fiber, making value-added yarn unattainable for small farms. Small custom mills can process fiber in batches as small as $0.45-0.91 \mathrm{~kg}$ (smaller than the yield of one muskox) - an extremely important consideration for producers with small herds as it enables them to maintain a yearly cash flow through yarn sales.

The ability to produce value-added goods, coupled with Internet sales to global markets, has changed the economic potential of muskox farming over the past decade. Despite the advances, market bottlenecks still affect producers; these include a lack of expertise with processing qiviut into quality yarn, and a limited amount of marketing and consumer education on qiviut qualities. These bottlenecks make it difficult for merchants to expand their qiviut distribution and limit their choice when processing their fiber. The model, as presented, depends on the producer selling all the yarn every year. This may become increasingly more difficult as the market expands.
The principal competition for farmed qiviut is qiviut from wild sources. The bulk of qiviut on the market is harvested from wild muskoxen, whose abundance fluctuates. The volatility of the wild qiviut supply, in conjunction with the limited amount of farmed qiviut, has created an unpredictable availability of raw fiber. To ensure supply, many commercial enterprises stockpile fiber from multiple sources: farmed, collected, and plucked from hides. The purchase price for raw wild qiviut is approximately $\$ 220-\$ 290$ per kilogram, depending on the condition and whether it is on a hide, while the current price for raw farmed qiviut is approximately $\$ 495$ per kilogram. However, the supply available from all sources is still quite limited, and the market is small. Therefore, after the initial purchase from the qiviut supplier, there is no subsequent price or labeling differentiation between wild and farmed qiviut at any point in the marketing channel from raw to finished garment. While raw wild qiviut is a close substitute good, the condition and supply of farmed qiviut are more consistent and command a price premium. The large price differential reflects the importance of access to a consistent supply in a tight market.

Historically, the price of raw farmed qiviut was determined by the initial non-profit farm in a relatively arbitrary manner because there was no established qiviut market (Watson and Groves, 1989). Currently, the price of raw farmed qiviut, while higher than that of wild qiviut, is still not high enough to cover production costs. The lack of market differentiation and consumer familiarity between wild and farmed sources may have prevented farmed qiviut from capturing the full value premiums associated with farm production once the qiviut market became more established. Farmed qiviut may be instrumental in the growth of the qiviut market. It has the potential to enhance the sustainability of the industry for both the subsistence communities that harvest wild qiviut and the agricultural community by ensuring a consistent supply and maintaining or increasing a market presence. Developing farming efforts in synchrony with wild harvest could alleviate commercial pressure on wild populations and stabilize market supply.

Regardless of source, the processed qiviut is marketed into two general sales channels: smaller retail stores, craft fairs, or farmer's markets selling yarn, roving, and small knitted items, and luxury boutique establishments selling fine knitted and woven garments. Qiviut yarns are often blended with other fibers such as cashmere, silk, merino wool, and bamboo. An Internet search (May 2015) found the price of a $28 \mathrm{~g}$ skein of $100 \%$ qiviut yarn averages $\$ 85$ (range $\$ 60-\$ 120$ ), and small finished goods such as hats, scarves, and cowls range from $\$ 150$ to $\$ 400$. Large finished garments, such as sweaters, blankets, and woven cloth made into designer suits, cost $\$ 600$ to $\$ 25000$ (Kissel, 2009). The qiviut market would seem to have substantial potential for growth; consumers spend $\$ 80$ billion on wool garments globally (Swan, 2013). Furthermore, the top $5 \%$ of consumers account for $38 \%$ of spending on 
wool apparel (Swan, 2013). Luxury apparel is the fastest growing segment of the fine fiber industry (Swan, 2013). The increasing popularity of fine fibers in luxury markets, coupled with the increased market demand for sustainable, organic, and heirloom products, could enable qiviut producers to use marketing to develop a larger niche for qiviut sales.

This analysis did not evaluate the revenue potential of finished garments for the modeled farm. Possible market expansions could include elite outdoor sportswear applications, expanded luxury markets, and greater use in fiber blends for commercial garment manufacturing. In addition to expanded uses for qiviut, other sources of revenue could include livestock workshops, head mounts, horn sales, and agrotourism. Muskoxen have value as a subsistence food animal, but no commercial market for muskox meat has been developed; hence, meat sales and hunt farms were not considered in this model.

Both MODC and LARS run successful agrotourism enterprises as a substantial source of revenue. While the agrotourism potential was not evaluated in the context of this feasibility analysis, the presence of these enterprises is a useful indicator of economic importance beyond the consumptive value. The social component of sustainability is well represented by the ticket sales and community interest in viewing the farm and livestock.

Monetary worth is often thought of as a measure of economic value, but the total economic value of an enterprise also includes social and environmental benefits not directly captured by the market. These non-monetary values, such as the value of environmental services, are also critical considerations for the sustainability of farming muskoxen and are not reflected in this enterprise budget. Research suggests that grazing in circumpolar regions is an important part of nutrient cycling and can improve the condition and productivity of circumpolar rangeland if properly managed (McKendrick et al., 1980; Olofsson et al., 2001). Social value to the community may include livestock diversity, cultural significance, and the existence of sustainable agriculture for circumpolar climates. While it is a challenge for producers to capture the non-market environmental value beyond the cost savings, niche product marketing associated with conservation, environmental sustainability and ecosystem stewardship could impact the value of qiviut and command a price premium in luxury and eco-markets.

\section{CONCLUSION}

The model we present is conceptual and designed to look at the economic feasibility of an established muskox farm within the context of a sustainable enterprise. Under a number of different scenarios, muskox farming can be economically viable within the limitations outlined in this study. The results indicated that economies of scale, the sale of value-added goods, and a lack of opportunity cost contributed to enterprise profitability. The study incorporated broad, primary costs associated with raising a non-traditional species. It did not address startup costs, which could be substantial, and specific details of land costs, interest rates, or sources of muskoxen for farming. These are all significant considerations, and any one of them could change the profitability equation.

However, creative agricultural endeavors in harmony with the environment have the greatest chance for success and sustainability in marginal ecosystems. The findings from this exercise suggest that using an indigenous species such as the muskox to harvest renewable landscape resources in marginal habitats, enhance ecosystem services in Alaskan pastures, and exploit niche fiber markets could promote a unique and sustainable agricultural model for the future.

\section{ACKNOWLEDGMENTS}

This study was generously supported in part by a grant from the National Institute of Food and Agriculture, U.S. Department of Agriculture, through the Western Sustainable Agriculture Research and Education Program (Award \#GW15005), the Animal Resources Center UAF, and the Department of Veterans Affairs. Any opinions, findings, conclusions, or recommendations expressed in this publication are those of the authors and do not necessarily reflect the view of the U.S. Department of Agriculture or the Department of Veterans Affairs. Publication costs were funded by a generous grant from the Office of the Vice Chancellor for Research, UAF.

We would like to thank Dr. John Blake and Emma Boone at LARS, and Mark Austin and Janelle Curtis at MODC for providing the data and a wealth of information that made this research possible. We thank Dr. H. Charlie Sparks for his invaluable assistance in accounting expertise that was used to develop the enterprise budget. We are grateful for the thoughtful feedback from three anonymous reviewers. Their insight proved invaluable to this manuscript.

\section{REFERENCES}

Adamczewski, J.Z., Kerr, W.M., Lammerding, E.F., and Flood, P.F. 1994. Digestion of low-protein grass hay by muskoxen and cattle. The Journal of Wildlife Management 58(4):679-685. https://doi.org/10.2307/3809682

Alaska State Legislature. 2014. Alaska statutes 2014. In: Fish and game code: Definitions. Juneau: Alaska State Legislature.

Ansari-Renani, H.R., Mueller, J.P., Rischkowsky, B., Seyed Momen, S.M., Ehsani, M., and Moradi, S. 2013. Observations on the efficiency of using different cashmere combs. Small Ruminant Research 114(2-3):220-224.

https://doi.org/10.1016/j.smallrumres.2013.06.013

Boehlje, M.D., and Eidman, V.R. 1984. Farm management. New York: J. Wiley \& Sons. 
Bond, J. 2011. Enterprise budget for alpacas. Agribusiness Finance Report 11-01. Fort Collins: Department of Agriculture and Resource Economics, Colorado State University. 5 p.

Boyd C.S., Collins, W.B., and Urness, P.J. 1996. Relationship of dietary browse to intake in captive muskoxen. Journal of Range Management 49(1):2-7. https://doi.org/10.2307/4002717

Cortright, L. 2006. The miracle of the muskox. Wild Fibers 2006(Summer):32-43.

Foulke, T., Torok, S.J., Taylor, T., and Bradley, E. 2001. Enterprise budget: Bison cow-calf, short grass prairie, eastern Wyoming. Laramie: Cooperative Extension Service, College of Agriculture, University of Wyoming.

Gillespie, J.M., and Schupp, A.R. 2002. The role of speculation and information in the early evolution of the United States ostrich industry: An industry case study. Review of Agricultural Economics 24(1):278-292. https://doi.org/10.1111/1467-9353.00097

Hofstrand, D. 2008. Oppportunity cost. Ag Decision Maker, File C5-210. Ames: Extension and Outreach, Iowa State University. https://www.extension.iastate.edu/agdm/wholefarm/html/c5210.html

Jones, P., and Perry, P. 2013. Unit 18 muskox. In: Harper, P., ed. Muskox management report of survey and inventory activities 1 July 2010-30 June 2012. Species Management Report ADF\&G/DWC/SMR-2013-2. Juneau: Division of Wildlife Conservation, Alaska Department of Fish and Game. 1-16.

Kissel, W. 2009. Rare hair. Robb Report, February 2009:68.

Kornegay, J.L., Harwood, R.R., Batie, S.S., Bucks, D., Butler Flora, C., Hanson, J., Jackson-Smith, D., et al. 2010. Toward sustainable agriculture systems in the 21 st century. Washington D.C.: The National Academies Press.

Kumm, K.-I. 2009. Profitable Swedish lamb production by economies of scale. Small Ruminant Research 81(1):63-69. https://doi.org/10.1016/j.smallrumres.2008.11.006

McGregor, B.A. 2012. Properties, processing and performance of rare natural animal fibres: A review and interpretation of existing research results. Canberra, A.C.T., Australia: Rural Industries Research and Development Corporation. 103 p.

McKendrick, J.D., Batzli, G.O., Everett, K.R., and Swanson J.C. 1980. Some effects of mammalian herbivores and fertilization on tundra soils and vegetation. Arctic and Alpine Research 12(4):565-578.

https://doi.org/10.2307/1550501
Olofsson, J., Kitti, H., Rautiainen, P., Stark, S., and Oksanen, L. 2001. Effects of summer grazing by reindeer on composition of vegetation, productivity and nitrogen cycling. Ecography 24(1):13-24. https://doi.org/10.1034/j.1600-0587.2001.240103.x

Robertson, M.A. 2000. Maximizing qiviut growth in muskoxen. MS thesis, School of Natural Resources and Agricultural Science, University of Alaska, Fairbanks.

Rowell, J.E. 1990. The muskox. In: Holst, B., ed. International Studbook for Muskox, Ovibos moschatus. Copenhagen: Copenhagen Zoo. 2-22.

Rowell, J.E., Lupton, C.J., Robertson, M.A., Pfeiffer, F.A., Nagy, J.A., and White, R.G. 2001. Fiber characteristics of qiviut and guard hair from wild muskoxen (Ovibos moschatus). Journal of Animal Science 79(7):1670 - 1674.

Rowell, J.E., Sousa, M.C., and Shipka, M.P. 2007. Estrous synchronization and the male effect in captive muskoxen. Canadian Journal of Animal Science 87(4):535-538. https://doi.org/10.4141/CJAS06036

Saitone, T.L., and Sexton, R.J. 2007. Alpaca lies? Speculative bubbles in agriculture: Why they happen and how to recognize them. Review of Agricultural Economics 29(2):286-305. https://doi.org/10.1111/j.1467-9353.2007.00343.x

Swan, P. 2013. Australia's wool in a competitive fiber market. In: Australian Bureau of Agriculture and Resource Economics and Sciences Outlook, Canberra, Australia.

Watson, R.B., and Groves, P. 1989. An economic appraisal of domesticated muskox husbandry. In: Proceedings of the Second International Muskox Symposium, 1-4 October 1987, Saskatoon, Saskatchewan, Canada. A40-A41.

White, R.G., Rowell, J.E., and Hauer, W.E. 1997. The role of nutrition, body condition and lactation on calving success in muskoxen. Journal of Zoology 243(1):13-20. https://doi.org/10.1111/j.1469-7998.1997.tb05752.x

Wilkinson, P.F., and Teal, P.N. 1984. The muskox domestication project: An overview and evaluation. In: Klein, D.R., White, R.G., and Keller, S., eds. Proceedings of the First International Muskox Symposium, 22-25 May 1983, University of Alaska, Fairbanks. 162-166. 